\title{
БОЈАН ВУКАДИНОВИЋ
}

Мегатренд универзитет у Београду, Факултет за културу и медије, Београд

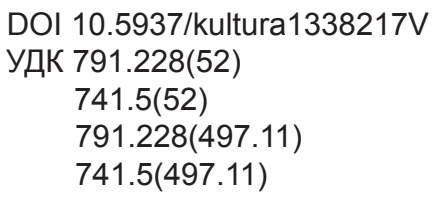

прегледни рад

\section{СРПСКА ПУБППКА JATAHCKA AHWMALUNA, ФИЛМОВИ И СТРИПОВИ}

Сажетак: Текст се бави истраживањем проиеса упознавања српске публике са јапанском популарном културом, а превасходно се то односи на стрип и анимацију. Представљен је кратак историјат стрипа у бившој Југославији, потом су наведени и неки од првих сусрета српске публике са јапанским анимираним серијама. Објашьени су термини „, аниме“ и „манга“, юихов типичан развој у Јапану, а следи и преглед феномена који су заслужни за юихову популарност у остатку света. Наводе се сајтови www.bg-anime. com и www.anime-overdose.com који су добрим делом заслужни за промоцију јапанске популарне културе у Србији, из тога следи кратак преглед рада друштва Сакурабана. Затим, представљене су неке од карактеристика и тематских подела у аниме и манга индустрији, потом су представљене карактеристике манга стила, као и приказ како су оне прихваћене у Србији.

Кључне речи: аниме, манга, стрип, популарна култура, Јапан, Србија, Сакурабана, бг-аниме, Јапанизам

Стрип је у некадашњој Југославији био присутан још из периода пре Другог светског рата, и „живео“ је код нас скоро до увођења санкција и цепања државе током деведесетих година двадесетог века. Могло би се рећи да је период између 70-их и 90-их година представљао златно доба стрипа за овај регион, барем када су тиражи стрипова и других штампаних медија у питању. У прилог томе се често наводи чињеница да је Стрипотека имала тираж од 80.000 издања, 


\section{БОЈАН ВУКАДИНОВИЋ}

што је данас незамисливо за неки стрип или магазин на подручју Србије, али и целе бивше Југославије. Стрип су читали и стари и млади и представљао је део свакодневице у Југославији. Међутим, то се у великој мери променило након цепања државе, ратних дејстава и санкција у Србији.

\section{Јапанска анимаџчја и стрип у Србији}

Српска публика је почела да се упознаје са јапанском анимацијом какву данас познајемо крајем осамдесетих година, када су на првом и трећем телевизијском каналу биле приказиване анимиране серије као што су „Грандзорт“, „Роботек“, „Плава принцеза“, „Сребрни јахачи и звездани шерифи“ (слика 1). Тада су анимирани филмови називани „цртаћи“ и претпостављало се да су они намењени искључиво деци. Међутим, у Јапану је присутно другачије схватање анимираних филмова и стрипова. Јапански цртаћи су веома рано почели да на стрип гледају као на медиј који има задатак да пренесе одређену причу публици која није нужно млађа од 15 година. У то време су публику чинила углавном деца, и та публика није правила велику разлику између цртаћа насталих у Азији и оних из других делова света, али она је постојала. Разлике су се огледале у стилу цртежа, броју епизода, а пре свега по причама које су биле озбиљније и намењене мало старијој публици него што се мислило у Србији.

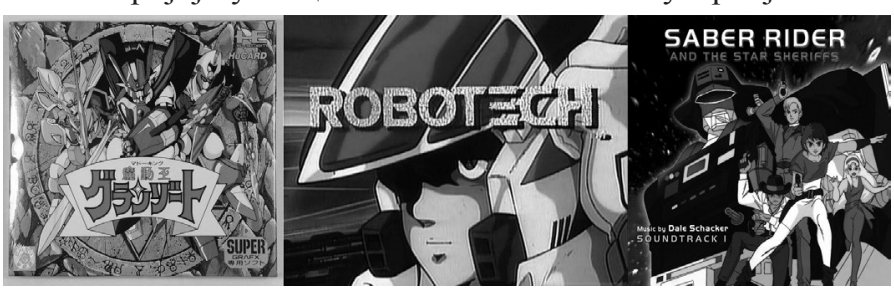

Слика 1

Увођењем санкција, условно речено, долази до „смрти стрипа“, драстично се смањује број читалаца стрипа, људи више немају времена нити новца за стрип. Држава запада у изолацију, већина стрипова и магазина се не издаје и у том периоду се губе читалачке навике и међу читаоцима „лаких“ штива.

Након првог сусрета српске публике са јапанском анимацијом дошло је до паузе која је трајала скоро целу деценију. Они који су као мали гледали и волели цртаће сећали су се да су се неки од њих разликовали од других по озбиљнијој тематици. Укинуте су санкције и омогућен је лакши проток информација и робе кроз земљу, што је љубитељима цртаног филма дало шансу да потраже копије својих омиљених анимираних серија из младости. Та потрага је мали број 


\section{БОЈАН ВУКАДИНОВИЋ}

људи довела до бројних информација везаних за медије из Јапана, а они су покушали са пријатељима да поделе оно што су открили.

\section{Основни термини}

Аниме ${ }^{1}$ је назив који се користи за све анимиране филмове који су настали на тлу Јапана. Специфични су по свом стилу и по разноликости тема које обрађују. Анимација у јапанским анимираним серијама је углавном јефтинија јер је у питању телевизијска продукција са малим буџетом. Изузетак су дугометражни филмови којима се посвећује већа пажња и чија је израда далеко скупља.

Манга ${ }^{2}$ је назив за стрипове који су стварани у Јапану и у многоме се разликују од стрипа који је српска публика имала прилику да упозна у претходном периоду. Као и аниме, манга стрипови се истичу по специфичном стилу, али и по томе што се објављују као веома дугачке серије. У Јапану се стрип сматра јефтином забавом и стога је огромна већина манги рађена у црно-белој техници, са изузетком насловница и евентуално првих пар страна које имају за циљ да дочарају стил цртежа.

Уколико неки манга стрип доживи велику популарност, прилично је извесно да ће добити и своје аниме издање. У Србију је већина аниме серија долазила преко дистрибутера из Шпаније, Француске или Америке. Највише филмова и серија које је наша публика имала прилику да види било је из продукцијске куће Manga Entertainment ${ }^{3}$ (слика 2), која је имала специфичан логотип, и отуда је дошао термин „манга цртаћи“ који је веома дуго био присутан међу српском публиком.

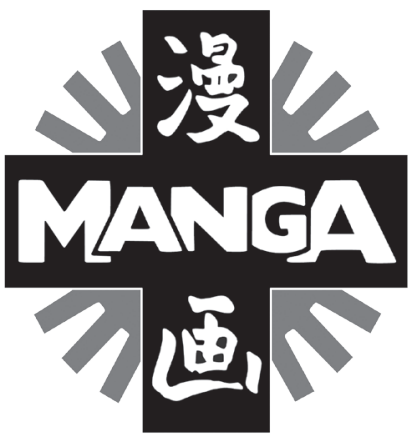

Слика 2

1 Аниме - назив за јапанске анимиране филмове који је настао од енглеске речи animation.

2 Манга - назив за јапанске стрипове. Реч је сковао Хокусаки Кацушика (1760-1849.) У буквалном преводу значи „ћудљиве слике“.

3 Manga Entertainment - лиценцорска кућа из САД за Велику Британију, Канаду, Француску, Аустралију и Нови Зеланд. 


\section{БОЈАН ВУКАДИНОВИЋ}

\section{Долазак (повратак) анимеа у Србију}

Захваљујући заљубљеницима у јапанску анимацију појавили су се први пиратски канали услед чега се повећала популарност аниме продукције у Србији. Прве копије анимираних серија и филмова из Јапана биле су преношене од особе до особе на видео касетама и другим носачима медија. Те серије и филмови су представљали штиво које није било за свакога. Аниме је почео да представља симбол за елитну публику алтернативне културе у Београду крајем деведесетих година и почетком двехиљадитих. Један од главних разлога зашто је дошло до тога је уверење велике већине грађана у то да су цртани филмови и стрипови само за децу. Сматрано је чудним и детињастим да неко старији од 10 година конзумира било које од та два. Због страха од прекора околине дошло је до тога да се аниме не даје свакоме и да се не прича много о њему.

Када је стрип у питању, до манги је било много теже доћи како због цене тако и због чињенице да у Србији не постоји ниједан дистрибутер. Али, са друге стране љубитељи стрипа у Србији су имали прилику да се сусретну са анимираним филмовима из Јапана и мишљења о њима су била подељена.

Захваљујући развоју телекомуникационе инфраструктуре и интернета у Србији, олакшава се приступ информацијама и различитим мултимедијалним садржајима. Ту чињеницу су појединци искористили и потражили информације о серијама и филмовима које су волели. Тада почиње да се открива која је тачна разлика између цртаћа и анима, као и шта су заправо манге и по чему су специфичне.

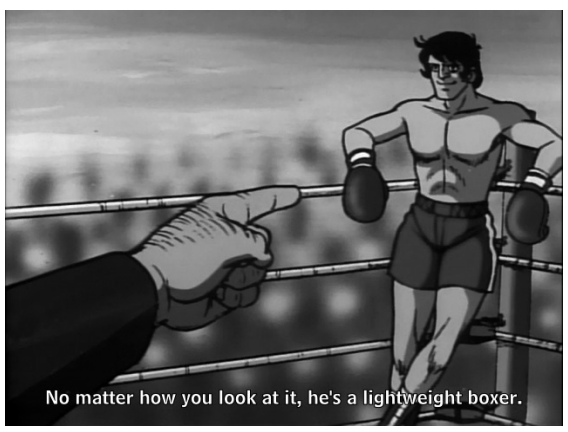

Слика 3

Један феномен на интернету је посебно заслужан за раст популарности јапанских анимираних серија, а то је fansubing (слика 3). Fansub (или Fansub групе) је кованица настала коришћењем енглеских речи fan-љубитељ и subtitle-филмски титлови, и представља групе људи окупљене са циљем да из љубави према јапанским анимираним серијама пре- 


\section{БОЈАН ВУКАДИНОВИЋ}

воде исте и деле их бесплатно са онима који не знају јапански језик, а желе да их гледају. Fansub групе су у великој мери допринеле развоју популарности анимеа јер је веома мали број серија из Јапана био објављиван на западу. Поред fansubing-а постоји и scanlation и он представља превод стрипова са јапанског на енглески и бесплатно дељење истих заинтересованима путем интернета. Овај феномен је на интернету узео маха, па су на то реаговале бројне јапанске издавачке куће, али и амерички дистрибутери. Проблем је био у илегалној дистрибуцији видео материјала, али су Fansub групе имале пуно право да дистрибуирају своје преводе. Нађено је решење које је било прихватљиво за продукцијске куће и за Fansub групе. Направљена је сарадња између дистрибутера и појединих Fansub група на подручју Америке. Преводиоци су добили прилику да преводе и да за то буду плаћени, јер је постало могуће да сви који воле аниме уз малу надокнаду легално гледају преведене серије на интернету. Међутим то није било коначно решење за остатак света, стога Fansub групе и даље постоје.

Аниме и манга култура су веома дуго биле доступне малобројнима који су поседовали рачунаре и разумели енглески језик. Они који су се сусрели са новим аниме серијама су неретко желели да своје усхићење поделе са својим пријатељима, што су и радили. Број људи који су се упознавали са светом анима се повећавао, али је то и даље текло алтернативним путевима, далеко од очију јавности.

Неколицина фанова из Србије желела је да открије има ли још заљубљеника у аниме и манге са којима би могли да размене мишљења и препоруке. Први корак ка томе било је отварање интернет форума и позивање свих познаника да му се придруже, а све са идејом да се отварају расправе, препоручују серије, филмови и манге. Раст интернет комуне љубитеља анимеа и манги омогућио је многима да се осећају прихваћено у друштву које у том тренутку није показивало разумевање за ову супкултуру.

Интернет сајтови посвећени анима и манга серијама, отварали су се и гасили на српском говорном подручjу, а до данас опстала су два која активно функционишу: www.bg-anime.com-портал са вестима, форум и Fansub група; www.anime-overdose.com - сајт и форум који сакупља преводе аниме серија и манги.

Чланови сајта www.bg-anime.com су почели да се окупљају са идејом да се оснује организација која би се бавила промоцијом јапанске поп-културе у Србији. Поред тога, један од циљева била би борба против уверења да су стрипови и 


\section{БОЈАН ВУКАДИНОВИЋ}

цртани филмови искључиво намењени деци. Тако је настала невладина организација „Сакурабана“ која званично бива основана тек 2007. године, више од годину дана од настанка идеје и подношења документације.

Сакурабана Београд од свог настанка ради на промоцији јапанске популарне културе, а у прилог томе стоји и фестивал Јапанизам, који се одржава већ пет година за редом (слика 4). А о успеху рада друштва говори чињеница да је на фестивалу одржаном 2012. године било преко 6000 посетилаца за четири дана (слика 5).

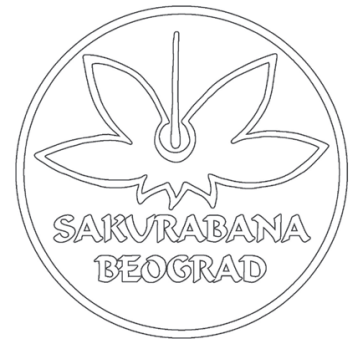

Слика 4

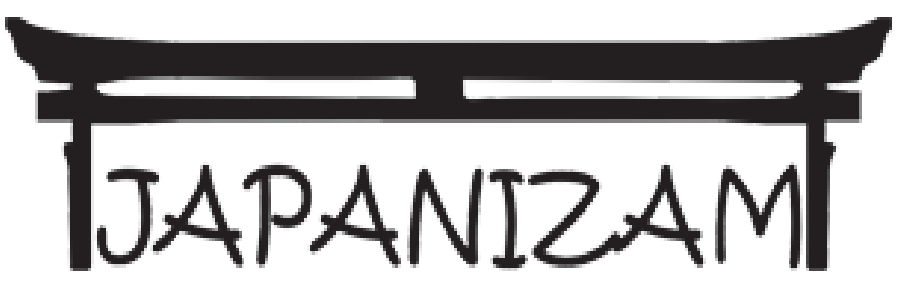

Слика 5

\section{Прихватање јапанског стрипа и анимираног филма у Србији}

У Јапану су анимирани филм и стрип прихваћени као и сваки други медиј, што значи да не постоји ограничење у погледу старости или пола њихових конзумената. Када су аниме и манга у питању поред уобичајене жанровске поделе на акцију, комедију, драму, итд. постоје и топографска и тематска подела. Захваљујући оваквој подели долази до тога да свако може пронаћи стрип у складу са својим интересовањима.

Топографска подела жанрова се односи на старосну доб и пол публике. Постоји пет основних подела:

Kodomo - (јап. деца) жанр намењен најмлађима, најчешће је едукативног типа

Shojo - (јап. девојчица) жанр намењен млађој женској публици (10-18 година) 


\section{БОЈАН ВУКАДИНОВИЋ}

- Shounen - (јап. дечак) жанр намењен дечацима (10-18 година)

- Seinen - (јап. мушкарац) мушка публика (18-30 година), озбиљније теме, криминалистика

- Josei - (јап. жена) женска публика старија од 18 година

Тематска подела постоји да би људима олакшала одабир остварења која су у складу са њиховим укусом. Она има за циљ да детаљније опише радњу једног анима/манга остварења. Веома је опширна и стално тежи ширењу зарад детаљнијег означавања неког наслова.

Примери тематске поделе:

Sentai - Група супер-хероја који спасавају свет (Моћни ренџери)

Mecha - Један од централних елемената су велики роботи којима управљају људи

Maho shojo - Гавни лик је девојка са магичним моћима

Један аниме/манга наслов мешавином жанрова, топографских и тематских подела покушава да се пробије до одређене публике. У Јапану се редовно спроводе истраживања о интересовањима тамошње публике са циљем да се направи штиво за свакога. У Србији, када је стрип и анимирани филм у питању, не постоји свест о оваквим поделама.

\section{Специифичности манга стила}

У манга стриповима се користе различити стилови, али се могу извући одређене карактеристике које су присутне код великог броја издања.

Читање са десна на лево - Манге се, као што је у природи јапанског језика, читају са десна на лево. Поједина манга издања која се објављују у Европи и Америци су прерађена и прилагођена локалном становништву и могу се читати са лева на десно. Међутим, све је више аутора који захтевају да се приликом превода не мењају стране и да буду верне оригиналу. Ово је прва, а можда и највећа замерка љубитеља стрипа у Србији. Љубитељи традиционалног стрипа најчешће приликом сусрета са овим проблемом одустају од даљег читања.

Велике очи - Карактеристично је за манге да ликови у њима имају веома велике очи, што није случај са класичним стрипом. Што је неки лик млађи, то су му веће очи у поређењу са главом. Један од првих људи који је почео да стилизује своје 


\section{БОЈАН ВУКАДИНОВИЋ}

ликове у стриповима на овај начин је Осаму Тезука ${ }^{4}$. Њега зову Бог (отац) манге јер је поставио бројне стандарде када су манге и аниме у питању. Не постоји јединствен одговор на питање зашто је Осаму Тезука почео да црта велике очи. Неки од могућих одговора су да је то преузео од ликова Волта Дизнија, други тврде да то има везе са модним скицама које су биле популарне после Другог светског рата, док трећи пак наводе да је то преузето од ликова из Хана-Барбера цртаних филмова. Ово је једна од првих ствари које људи у Србији примећују када се сусретну са мангама. Прве реакције су обично негативне, јер изгледају неприродно и крајње необично за некога ко је навикао на стандардни цртеж присутан у стриповима из других делова света. Међутим, млађа публика, старости до 17 година, много лакше прихвата овај стилски елемент и не показује никакву одбојност према њему.

Велики број издања - У Јапану се манге објављују у магазинима који излазе недељно или месечно. Један магазин обично у себи садржи десетине епизода различитих манги које се настављају из броја у број. Уколико је неки манга наслов довољно популаран и интересантан публици наставиће да излази, а после неког времена (уколико је довољно популаран) може добити своје засебно издање, тј. поглавље. Посебна поглавља која се објављују се називају tankobon, у просеку имају око 200 страна и представљају колекционарска издања. ${ }^{5}$ На манге се у Јапану гледа као на јефтину забаву за целу нацију, стога се магазини штампају на јефтином рециклажном папиру, лако су доступни, а цена једва да покрива трошкове штампе. Аутор манге (мангака) има за циљ да што дуже буде присутан на тржишту, стога мора да пронађе начин да одржи пажњу читалаца, што доводи до великог броја епизода које се међусобно надовезују.

Када је српска публика у питању, чињеница да постоји велики број епизода не представља проблем, уколико се читаоци навикну на стил. Приметно је да старија генерација не воли серије које имају превише епизода јер је за то неопходно издвојити много времена, док је омладина у Србији расположена да прати маратонске наслове.

Црно-бели стрип - Да би мангака постигао да нацрта двадесетак страна недељно који треба да буду објављени у магазину, неопходно је да се скрати процес стварања стрип-табли,

4 Schodt F.L., Manga! Manga! The World of Japanese Comics, SAD 1997, pp. 63.

5 Schodt F.L., Manga! Manga! The World of Japanese Comics, SAD 1997, pp. 12. 


\section{БОЈАН ВУКАДИНОВИЋ}

а један од првих предуслова је био да се не боје све стране. Најчешће се у магазинима објављују првих пар страна које су у боји и које имају за циљ да дочарају изглед света у коме се одвија радња. Црно беле стране у Србији нису представљале велики проблем код публике, али су на први поглед одавале утисак да су питању јефтина издања ако би се поредила са француским стрип албумима.

Кадрови - Пионири манга стила су били у великој мери инспирисани играним филмовима и то су преносили на стрип. Препознатљив је начин постављања кадрова у мангама који оставља утисак налик филмским сценама. Поред специфичних кадрова, у мангама је веома ретко присутан текст наратора и много се чешће препушта да цртеж говори сам за себе.

Од манге до анимеа - Манге које доживе велику популарност у Јапану често добијају и своје аниме издање. Аниме издања некада имају за циљ да привуку нову публику која ће почети да чита мангу, или просто постизање још веће популарности. Ретки су случајеви где је редослед објављивања ишао другачије, али се и то догађало. Захваљујући аниме серијама и филмовима повећана је популарност јапанске популарне културе у Србији. Публика у Србији се најчешће сусреће са аниме серијама или филмовима, па тек потом са мангама.

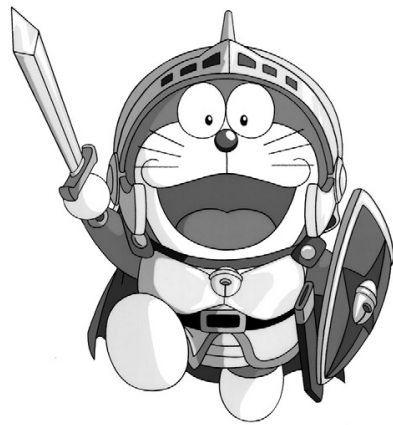

Слика 6

Аниме и манге су у свету од самог почетка имале проблема са објављивањем и јавним приказивањем, пре свега због закона о цензури, тј. због непостојања таквог правног оквира. У Америци је законом дефинисан начин означавања материјала који је намењен старијој публици, стога је неким јапанским остварењима омогућен долазак на америчко тржиште. Међутим, поједине компаније су одлучиле да анимиране серије и филмове цензуришу и прилагођавају млађој публици како би било могуће телевизијско емитовање, што је довело до негодовања публике. 


\title{
БОЈАН ВУКАДИНОВИЋ
}

У Србији је на снази закон 6 по ком је неопходно означити за коју старосну доб је намењен приказивани материјал, али највећи проблеми долазе приликом одабира анимираних серија и њиховог оцењивања, јер су и даље присутна уверења да су цртани филмови искључиво за децу. Мишљења по овом питању су и даље веома подељена, али је све више људи који разумеју да су анимација и стрип пре свега медиј и да су различита остварења намењена различитој публици. Популација старости до 25 година тренутно има најраширенију свест о томе. До тог помака је дошло захваљујући интернету и свеприсутности јапанске популарне културе у медијима.

\section{ЛИТЕРАТУРА:}

Schodt F. L., Manga, Manga! The World of Japanese Comics, SAD 1997.

Masanao A. i Julius Wiedemann, Manga design, Italy 2004.

Bojan Vukadinović

Megatrend University, Faculty of Culture and Media, Belgrade

\section{SERBIAN PUBLIC, JAPANESE ANIME, FILMS AND COMICS}

\begin{abstract}
In Serbia, appearance of the first anime concurred with their appearance in the rest of Europe. However, reception of the Japanese popular culture was dramatically slower due to the long time Serbia had spent in isolation and under sanctions. Unfortunate regressive consequences of this isolation have even affected reading habits. With the closure of this dark period, Serbian public was left alone and forced to fight for its preferences. Today, the situation is much better since new generations have the opportunity to learn about the Japanese popular culture thanks to growing internet and the work of Sakurabana Association and other individuals. Young people show great interest in Japanese comics since the nature of this media is to convey massages in a very easy and efficient manner. Fact is that there is already a considerable number of people in Serbia who share their love for the Japanese popular culture, which promises even wider acceptance and a growing audience.
\end{abstract}

Key words: anime, manga, comics, popular culture, Japan, Serbia, Sakurabana, bg-anime, Japanism

6 Обавезујуће упутство о понашању емитера (Кодекс понашања емитера), у Сл. гласник РC, бр. 63/2007 